\title{
TARGET AND NON-TARGET IMPACTS FROM DIAZINON APPLIED AGAINST DASINEURA MALI IN A CANTERBURY APPLE ORCHARD
}

\author{
G.M. BURNIP, A.R. GIBB and D.M. SUCKLING
}

\author{
HortResearch, P.O. Box 51, Lincoln
}

\begin{abstract}
The control of apple leafcurling midge (Dasineura mali) with diazinon was investigated as part of an Integrated Fruit Production programme. A soil drench was applied against the emerging adults of the first generation (pre-flowering), and compared with a foliar application against the second generation (early December). Nontarget effects on the biodiversity of ground dwelling arthropods were examined using pitfall traps before and after diazinon applications, and on arboreal diversity using brushed leaf samples. Drench, foliar spray, and a combination of these treatments, all reduced percentage of damaged shoots compared to untreated plots. Drench and foliar applications gave similar results. Little impact on ground-dwelling arthropod biodiversity was detected following the drench or foliar applications. The biodiversity of foliage-dwelling (mainly beneficial) arthropods showed a significant reduction after foliar treatment.
\end{abstract}

Keywords: Dasineura mali, IFP, indicator, biodiversity, diazinon.

\section{INTRODUCTION}

The importance of apple leafcurling midge (Dasineura mali), originally regarded as a secondary apple tree pest in New Zealand, has increased considerably in recent years, with up to $20 \%$ of harvested fruit infested with pupal cocoons in some Waikato and Hawkes Bay orchards (Tomkins et al. 1995). D. mali maggots cause most damage to young trees by stunting growth of terminal shoots. In Canterbury, economic damage to mature trees has not been quantified, but appears to be limited. However, D. mali can reduce photosynthesis (Allison et al. 1995), and in 1997 D. mali cocoons were recorded for the first time on Canterbury fruit submitted to ENZA (N. Peck, pers. comm.). The development of regional pest management strategies are necessary for this pest, due to regional variability in its abundance and the number and timing of generations.

Insecticidal control of immature $D$. mali is frequently poor, due to the protection afforded by the rolled leaves they inhabit. However, a short 'window of opportunity' exists where insecticidal control can be effective, with sprays timed for adult emergence and egg laying. In Canterbury, a foliar application of diazinon is not possible against the first generation because it coincides with flowering (Burnip unpublished data). However, while a foliar application of diazinon timed against the second generation eggs in December can adequately reduce $D$. mali populations, broad-spectrum insecticides like diazinon are likely to have non-target disruptive effects on Integrated Fruit Production (Bradley et al. 1997; Shaw et al. 1997). As significant reductions in pest management inputs are possible when natural control mechanisms are optimised (Walker et al. 1997), the development of a more sustainable pipfruit production system may be limited by such insecticide use (Wearing 1997). This trial compares the efficacy of diazinon applied pre-flowering to the soil, targeting pupal and adult $D$. mali of the first generation, with a foliar application targeting $D$. mali eggs of the second generation. The non-target effects of diazinon are also examined. 


\section{MATERIALS AND METHODS}

The 8 ha. trial was carried out at a ca. 7 year old Canterbury pipfruit orchard, during 1997-98. Twelve plots were used (4 treatments x 3 reps), each comprising 12 rows (ca. $85 \mathrm{~m}$ long; $3 \mathrm{~m}$ x $5 \mathrm{~m}$ tree and row spacings) of cv. 'Royal Gala' apples. Plots were surrounded by either 12 rows of cv. 'Fuji' apples, or a dense shelter belt (Matsudana willow, ca. $10 \mathrm{~m}$ high $\times 2 \mathrm{~m}$ thick). Timed ground and foliar diazinon applications were also made to these 'Fuji' buffer plots to reduce $D$. mali immigration into the treatment plots, and all data were collected from the middle two rows of each plot.

\section{Diazinon trial}

The following treatments were applied in a randomised block design: 1) Diazinon (Basudin 600 EW, 4 litres/ha) was applied as a soil drench on 24.9.97 (Royal Gala tight cluster), by a herbicide boom-sprayer, and followed immediately with $15 \mathrm{~mm}$ of micro-irrigation. The treated area comprised $2 \mathrm{~m}$ either side of the trees and extended past the drip-line; 2) Foliar application of diazinon (Basudin $50 \mathrm{WP}, 2 \mathrm{~kg} / \mathrm{ha}$ ) was applied 15.12 .97 by airblast sprayer (1500 litres of water/ha); 3) Treatments 1 and 2 combined; 4) No treatment.

Treatment efficacy was assessed in the field by recording D. mali infestation on ten extension shoots from each of ten trees randomly selected from each plot. Severity of infestation was assessed by recording the total number of leaves on each shoot examined and the proportion damaged. Treatments were assessed on 30.10.97 and 19.11.97 to assess the first generation population. The second generation was assessed on 13.1.98.

\section{Non-target impacts}

Ground dwelling arthropods were sampled using pitfall traps $(100 \times 100 \mathrm{~mm}$ pottles, 1/plot) containing ca. $50 \mathrm{ml}$ Gaults solution (Walker and Crosby 1988). Traps were operated for 72 hours, beginning 22.9.97 and 29.9.97 (pre- and post-drench), and 24.11.97 and 22.12.97 (pre- and post-foliar). Fifty apple leaves were also removed from each plot on 13.1.98. The leaves were brushed using a mite brushing machine and arthropod numbers recorded.

\section{Analysis}

Shoot infestation levels were compared using analysis of variance on angular transformed values. The Shannon-Wiener index of biodiversity was calculated for arthropods collected in pitfall traps, and also for those detected on brushed leaves. However, arthropods known to be OP-resistant were excluded from the brushed leaf analysis (Tetranychus urticae, Panonychus ulmi, Phytoseiulus persimilis) to avoid bias. Covariate analysis was used to investigate the impact of treatments on arthropod biodiversity, using diversity before treatment as a covariate.

\section{Diazinon trial}

\section{RESULTS AND DISCUSSION}

The incidence of D. mali-infested shoots was significantly lower in plots treated with soil applied diazinon, compared to untreated plots, at all three assessment dates (Table 1). Shoot infestation was also significantly reduced by foliar treatment (applied after the second assessment), compared to untreated plots. By the time of the third sample, fewer than $10 \%$ of shoots were actively growing, reducing the available feeding sites and impact of subsequent $D$. mali generations. At this time, no significant differences existed in $D$. mali shoot infestation between soil-treated and foliar treated plots. Although mean percent shoot infestation at January 13 was only $6 \%$ in plots which received soil and foliar treatments, this was not significantly less than plots with either soil or foliar treatments alone. This suggests the application of more than one diazinon treatment was unnecessary, given that both the soil drench and foliar applied treatments maintained $D$. mali populations below the economic threshold $(20 \%$ of shoots infested with eggs, Walker et al. 1997).

The assessment of the severity of the shoot infestation was considerably more time consuming than the much simpler determination of the percentage of shoot infestations per tree. There was a close correlation between the number of leaves infested per shoot and the number of shoots infested per tree on each date $\left(\mathrm{R}^{2}=0.94,0.86,0.74\right.$ for the three dates, each $\mathrm{P}<0.01,10 \mathrm{df})$. As the severity of shoot infestations in this Canterbury 
orchard was substantially lower than is typically observed in Waikato and Hawkes Bay orchards (Tomkins et al. 1997), the use of the simpler determination of the percentage of shoot infestations per tree might be sufficient in future Canterbury studies, unless the severity rises dramatically.

TABLE 1: Mean percent $( \pm \mathrm{SE})$ shoots infested with $D$. mali on 'Royal Gala' apples, under four management regimes, on three sample dates, at a Canterbury orchard, during 1997-98. Data are untransformed.

\begin{tabular}{|c|c|c|c|}
\hline Treatment & $\begin{array}{c}30.10 .97 \\
5 \text { weeks } \\
\text { post-drench }\end{array}$ & $\begin{array}{c}19.11 .97 \\
8 \text { weeks } \\
\text { post-drench }\end{array}$ & $\begin{array}{c}13.1 .98 \\
16 \text { weeks } \\
\text { post-drench }\end{array}$ \\
\hline
\end{tabular}

4 weeks post-foliar

drench (on 24.9.97)

foliar (on 15.12.97)

drench + foliar

untreated

$$
\begin{array}{r}
0.0 \pm 0.0 \mathrm{a}^{1} \\
13.7 \pm 1.2 \mathrm{~b} \\
0.3 \pm 0.2 \mathrm{a} \\
11.7 \pm 1.3 \mathrm{~b}
\end{array}
$$$$
0.3 \pm 0.0 \mathrm{a}
$$$$
14.3 \pm 2.5 \mathrm{a}
$$$$
12.0 \pm 3.8 \mathrm{~b}
$$$$
12.7 \pm 2.0 \mathrm{a}
$$$$
0.3 \pm 0.6 \mathrm{a}
$$$$
6.0 \pm 1.6 \mathrm{a}
$$

$16.7 \pm 4.4 \mathrm{~b}$

$35.0 \pm 4.3 \mathrm{~b}$

${ }^{1}$ Column entries with different letters were significantly different from each other $(\mathrm{P}<0.05)$, using paired t-tests on angular transformed values.

While this trial demonstrated the effectiveness of D. mali control using diazinon as a drench pre-bloom, similar studies in Nelson and Hawkes Bay have shown some variability in efficacy (Bradley pers. comm.). This could be due to soil type, the importance of application timing, the relatively low densities of $D$. mali present in Canterbury, or other unidentified factors, possibly related to the mode of action of the drench which is currently poorly understood. While the efficacy of the early-season drench and the mid-season foliar application were similar, the costs associated with the diazinon product for these two strategies were different (ca. $\$ 112$ and $\$ 67 /$ ha, respectively), but this difference was substantially offset by the reduced machinery costs associated with the boom sprayer application (ca. $\$ 9 / \mathrm{h})$, compared to airblast (ca. $\$ 35 / \mathrm{h}$ ).

\section{Non-target impacts}

The biodiversity of arthropods pitfall trapped before the drench application was not significantly different from the biodiversity in samples trapped three days after the drench (according to the covariate analysis on Shannon-Weiner values). Similarly, the foliar application did not significantly alter the biodiversity index in pitfall traps (Figure 1). The presence of relatively large numbers of a single taxon (Collembola), complicated interpretation of the biodiversity indicies, but no significant differences were evident when the Collembola were removed from the calculations.

Differences were found in the total numbers of Collembola trapped (range: 0857). In untreated plots, numbers of Collembola trapped increased between the predrench and pre-foliar application sample dates $(\mathrm{P}<0.05)$, whereas numbers in the drench treated plots remained similar. Similar differences were also found in the total numbers of lycosid and linyphiid spiders trapped in untreated and drench treated plots (range: $0-8)$, between these two sample dates $(\mathrm{P}<0.01)$.

It is surprising that a broad-spectrum insecticide such as diazinon should appear to have no discernible effect on ground-dwelling invertebrate fauna 3 days after application. The diazinon may have been washed through the sward profile, by the 15 mm of water applied. However, the diazinon did significantly reduce the A. mali population, although whether pupae or emerging adults were affected is not clear. It is possible that non-target arthropod mortality from the soil-applied diazinon was greatest at lower levels within the sward/soil profile. If so, this could account for the delayed reduction observed in Collembolla and spider numbers, as pitfall traps tend to sample the more active adult stages of arthropods, and immature life stages tend to occur lower within the profile. Additionally, immature stages may be more susceptible to diazinon. 


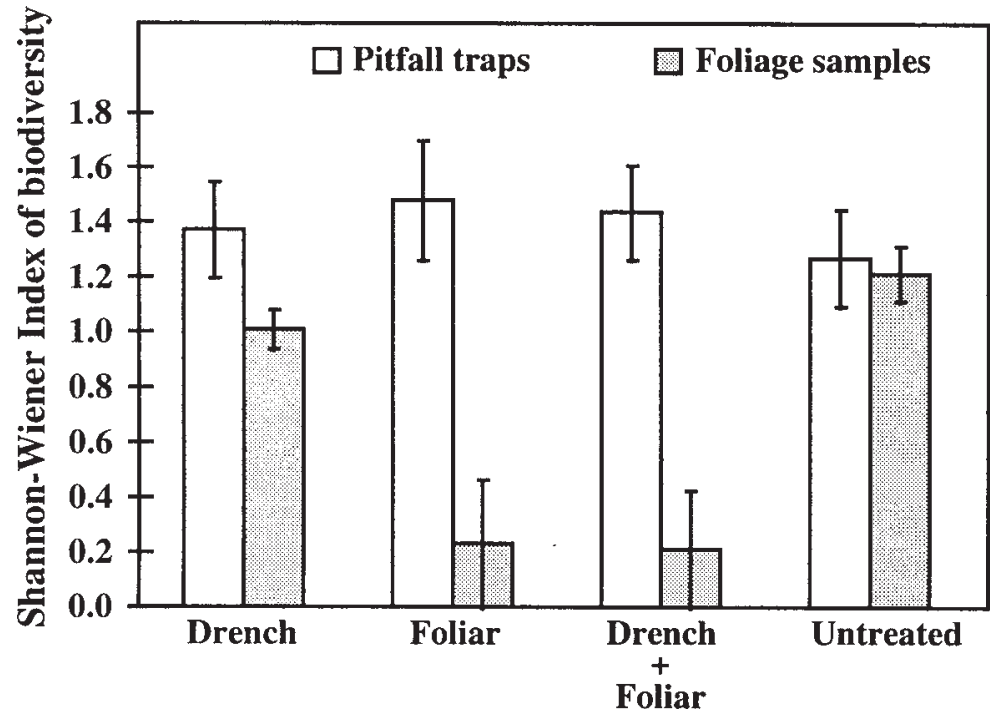

\section{FIGURE 1: Shannon-Wiener indices of arthropod biodiversity found in pitfall traps (grand mean of four samples, taken before and after the soil and foliar diazinon applications) and leaf samples (taken after the foliar diazinon application).}

Foliar treatments with diazinon had no effect on biodiversity trapped in pitfalls, but significantly reduced arthropod biodiversity on tree foliage, one month after application (Figure 1), compared to untreated plots ( $\mathrm{P}<0.05$, ANOVA; range: 0-8). The taxa assessed involved important natural enemies of key pests, and included: Stethorus sp.; Sejanus albisignata; cecidomyid and syrphid larvae; thrips; and tydeid, tarsonemid, and oribatid mites (Wearing 1997). This finding supports a previous study, where reductions in arthropod biodiversity from foliar applied organophosphate insecticides were also greatest on foliage samples, compared to pitfall traps (Suckling et al. 1997).

In conclusion, while results from efficacy trials in other regions have been less conclusive, results from this trial suggest that both a soil drench of diazinon targeting the first generation, or a foliar application targeting the second generation can maintain D. mali populations below the economic threshold in Canterbury orchards. Some nontarget effects of these treatments were found, depending on whether the diazinon was applied as a foliar spray or soil drench. Foliar application of organophosphate insecticides can lead to mite control problems through loss of natural enemies (Wearing 1997). The non-target implications of soil drenches on important natural enemies (eg. spiders) and pest control is unclear. However, we suggest that, if ecologically sustainable production systems are to be developed, sampling for the impact of pest management strategies on non-target species should be included in future trials where possible.

\section{ACKNOWLEDGEMENTS}

We would like to gratefully acknowledge T. Rutherford and B. Cassidy (Rutherford Orchards) for applying the diazinon treatments, and to G. Follas (Novartis) who supplied the diazinon product. Also to A.R. Tomkins, S.J. Bradley and J.T.S. Walker (HortResearch) for their advice on D. mali biology. 


\section{REFERENCES}

Allison, P.A., Meekings, J.S., Tomkins, A.R. and Wilson, D.J., 1995. Effects of leaf damage by apple leafcurling midge (Dasyneura mali) on photosynthesis of apple leaves. Proc. 48th N.Z. Plant Prot. Conf.: 121-124.

Bradley, S.J., Murrell, V.C Shaw, P.W. and Walker, J.T.S., 1997. Effects of orchard pesticides on Aphelinus mali, the woolly apple aphid parasitoid. Proc. 50th N.Z. Plant Prot. Conf.: 218-222.

Shaw, P.W. Bradley, S.J. and Walker, J.T.S., 1997. The impact of early season insecticides in an integrated fruit production programme on apple.Proc. 50th N.Z. Plant Prot. Conf.: 283-287.

Suckling, D.M., Wearing, C.H., Gibb, A.R., Burnip, G.M., Attfield, B. and Colhoun, K., 1997. Biodiversity in apple orchards: apple tree foliage and ground cover sampling. Proc. 50th N.Z. Plant Prot. Conf:: 541. Abstract.

Tomkins, A.R., Wilson, D.J., Allison, P.A., Thomson, C., Hutchings, S.O., Bedford, R.A. and Dow, B., 1995. Phenology and other key aspects of the ecology of apple leafcurling midge (Dasyneura mali) affecting control (Waikato) - year one. HortResearch Client Report to NZAPMB No. 95/197.

Tomkins, A.R., Wilson, D.J., Allison, P.A., Thomson, C. and Allison, P.A., 1997. Development of a system for managing apple leafcurling midge (Dasyneura mali) under integrated fruit production (IFP). HortResearch Client Report to NZAPMB No. 98/52.

Walker, J.T.S., Hodson, A.J., Wearing, C.H., Bradley, S.J., Shaw, P.W., Tomkins, A.R. Burnip, G.M., Stiefel, H.E. and Batchelor, T.A., 1997. Integrated fruit production for New Zealand pipfruit: evaluation of pest management in a pilot programme. Proc. 50th N.Z. Plant Prot. Conf:: 258-263.

Walker, A.K. and Crosby, T.K., 1988. The preparation and curation of insects. DSIR Information Series 163. Pp. 80.

Wearing, C.H. 1997. Indicators of sustainable pest management in orchard production systems. Proc. 50th N.Z. Plant Prot. Conf.: 506-513. 